\title{
Chapter 5 \\ Overview of Economic Viability and Social Impact of Renewable Energy Deployment in Africa
}

\author{
A. Khellaf
}

\begin{abstract}
Africa is endowed with a very important renewable energy potential. Exploited, this potential permits the continent not only to get out of the energy poverty it is suffering from but also to ensure a sustainable development. In the present work, the economic viability of renewable power generation is assessed and analyzed. Then an identification and discussion of the impacts that the renewable energy deployment could have on socio-economic progress, health, education, gender equity and rural development are carried out.
\end{abstract}

Keywords Africa - Electricity access - Renewable energy $\cdot$ Economic viability Social impacts $\cdot$ Health impacts

\subsection{Introduction}

Africa suffers from energy deficit. Indeed, though it represents $16 \%$ of the world population, it consumes only $3 \%$ of the power generated worldwide. More than 600 million Africans have no access to electricity [1]. The electrical networks are also plagued by technical problems. Because of aging and poorly maintained transmission and distribution networks, the electrical grids experience big losses and recurrent outage. In fact, $95 \%$ of the African countries experience electrical losses larger than the world average losses. Countries, such as Libya and Togo, experience staggering losses respectively of the order of 69.7 and $72.5 \%$ [1].

The grid system suffers also from high recurrence and high duration of outages. It has been reported that Senegal, Tanzania and Burundi experience unbelievable outages that sum up respectively to 45, 63 and 144 days/year [2]. Moreover, Africa suffers from a lack of access to clean fuels and modern technology for cooking.

\footnotetext{
A. Khellaf $(\bowtie)$

Centre de Développement des Energies Renouvelables,

BP 62, Route de l'Observatoire, 16340 Bouzareah, Algiers, Algeria

e-mail: a.khellaf@cder.dz 
About $60 \%$ of the African population rely on traditional firewood or charcoal air polluting stoves for cooking. The damage to health is enormous [3].

The present work deals with the deployment of renewable energy. More particularly, an assessment and an analysis of the viability of renewable energy deployment is carried out. The impacts of this deployment on socio-economic progress, health, education, gender equity and rural development are then identified and discussed.

\subsection{Economics of Renewable Energy Deployment}

The capacity of renewable energy deployment depends on a large part on the initial financial investment that is required for renewable power generation infrastructures deployment. The economic success of the renewable energy deployment is related to its financial viability, which depends on the deployment capacity in generating energy at a competitive cost.

\subsubsection{Capital Investment Cost}

Renewable energy deployment is capital investment intensive. In Table 5.1, capital costs of renewable and non-renewable power generation deployment are reported $[4,5]$. From this table, it can be seen that higher capital costs are required for

Table 5.1 Capital cost for renewable and non-renewable power generation systems [4, 5]

\begin{tabular}{l|l|l}
\hline Source & Technology & Installation cost $(\$ / \mathrm{W})$ \\
\hline \multirow{3}{*}{ Conventional source } & Nuclear plant & $4.27-7.93$ \\
\cline { 2 - 3 } & Natural gas combustion turbine & $0.49-0.81$ \\
\cline { 2 - 3 } & Natural gas combined cycle & $0.92-1.54$ \\
\cline { 2 - 3 } & Coal fired power plant & $1.88-3.90$ \\
\hline & Stand-alone biomass power plant & $2.87-5.75$ \\
\cline { 2 - 3 } & Geothermal power plant & 5.94 \\
\cline { 2 - 3 } & Hydropower & $2.28-4.73$ \\
\cline { 2 - 3 } & Solar PV power plant & $2.12-3.54$ \\
\cline { 2 - 3 } & Solar PV home system & $3.6-17.0$ \\
\cline { 2 - 3 } & Grid connected solar PV roof top system & $2.0-3.0$ \\
\cline { 2 - 3 } & Mini-grid system & $2.5-2.9$ \\
\cline { 2 - 3 } & CSP trough with storage power plant & $4.59-8.12$ \\
\cline { 2 - 3 } & CSP tower with storage power plant & $4.58-8.10$ \\
\cline { 2 - 3 } & Wind on shore power plant & $1.49-2.48$ \\
\cline { 2 - 3 } & Wind fixed bottom off shore power plant & $2.15-4.47$ \\
\cline { 2 - 3 } & Wind floating platform off shore power plant & $2.73-5.67$ \\
\hline
\end{tabular}


renewable energy deployment than for non-renewable deployment. Nonetheless, it is worth to note that wind technology deployment is competitive with the non-renewable source technologies. It has also been argued that, as the conventional source technologies are mature, it is more likely that their capital cost will not change much over the years. On the other hand, renewable technologies, with improvement in technologies and with the learning curve effect, capital costs are undoubtedly going to drop; making them more competitive with conventional energy source technologies.

Given the actual state of most of the African states economies, capital cost could be a serious hurdle for most of them. Fortunately, there are many funding opportunities focused or related to renewable energy that must be grabbed.

These opportunities should be sought from local or public sectors or from the development finance institutions. Among the development finance institutions, there is the World Bank that is ready for renewable energy deployment through its Climate Investment Fund and its Strategic Climate Fund [6]. There is also the African Development Bank which gets involved in renewable energy deployment through its Sustainable Fund for Africa and its Partial Risk Guarantees. Green Facility for Africa, African Development Fund, International Climate Fund, Global Environment Fund, Global Energy Efficiency and Renewable Energy Fund and Global Environment Facility Trust Fund are development finance institutions that are deeply involved in renewable energy deployment in Africa. Funding in Africa could be under the form of a loan, a rebate, a subsidy or a grant. The funding could also take the form of a technical support or an action of awareness and training.

\subsubsection{Renewable Power Generation Economic Viability}

There are different methods for assessing the economic viability of renewable energy production facilities deployment. The assessment could, for example, be based on the net revenue or on the production cost relative to the cost of production of a non-renewable energy production technology [3, 7]. The levelized cost of energy (LCOE) is usually used to provide an indication of the competiveness of energy generation of a given technology. In Table 5.2, the levelized cost of power generation based on renewable and non-renewable energy sources are reported $[8,9]$. From this Table, it can be noticed that Solar PV and wind systems connected to the grid are competitive with gas turbines. The same way, geothermal, bio-power and hydropower connected to the grid are competitive with gas turbines and combined cycles. Mini-grid and off-grid technologies for solar PV and wind remain expensive by comparison to grid connected technologies. Nonetheless, they offer flexibility and if power transport is taken into consideration, they will be more attractive. It must be added that different local aspects could affect the economic viability of renewable energy deployment:

1. The conversion technology in association with the local technical potential of the renewable energy source; 
Table 5.2 Levelized cost of energy for power generation $[8,9]$

\begin{tabular}{l|l|l}
\hline Source & Technology & LCOE $(\$ / \mathrm{kWh})$ \\
\hline Conventional source & Gas turbine & $0.10-0.15$ \\
\cline { 2 - 3 } & Combined cycle & $0.055-0.10$ \\
\cline { 2 - 3 } & Coal & $0.045-0.05$ \\
\hline \multirow{5}{*}{ Renewable source } & Solar PV utility & $0.06-0.26$ \\
\cline { 2 - 3 } & CSP power plant & $0.28-0.33$ \\
\cline { 2 - 3 } & Wind utility & $0.05-0.17$ \\
\cline { 2 - 3 } & Geothermal & $0.045-0.13$ \\
\cline { 2 - 3 } & Bio-power & $0.04-0.18$ \\
\cline { 2 - 3 } & Hydropower & $0.04-0.2$ \\
\cline { 2 - 3 } & Off- or mini-grid solar PV & $0.30-0.32$ \\
\cline { 2 - 3 } & Off- or mini-grid wind & $0.25-0.26$ \\
\cline { 2 - 3 } & Small hydro & $0.25-0.28$ \\
\hline
\end{tabular}

2. The local cost of material, labor and other matters that vary locally;

3. The location of the power system in relation to the transmission lines and to the consumers.

For wind energy, it has been reported that power generation is viable for wind speeds larger than $4 \mathrm{~m} / \mathrm{s}$ at $80 \mathrm{~m}$ above ground level. For solar PV, power generation is viable in the case where the global horizontal irradiance is larger than $1000 \mathrm{kWh} / \mathrm{m}^{2}$ year; while concentrated solar power (CSP) generation is viable in the case where direct normal irradiance (DNI) is above $1800 \mathrm{kWh} / \mathrm{m}^{2}$ year. It has also been found that the levelized cost of energy for power generation using CSP decreases with increasing DNI [10].

\subsection{Renewable Energy Deployment Social Impacts}

Renewable energy deployment has social impacts on different levels. The impacts could be at the socio-economic level, the improvement of quality of life, health and education.

\subsubsection{Socio-Economic Impact}

Renewable energy influences positively the contribution to industrial development and job creation throughout the whole chain of the energy deployment. As shown in 


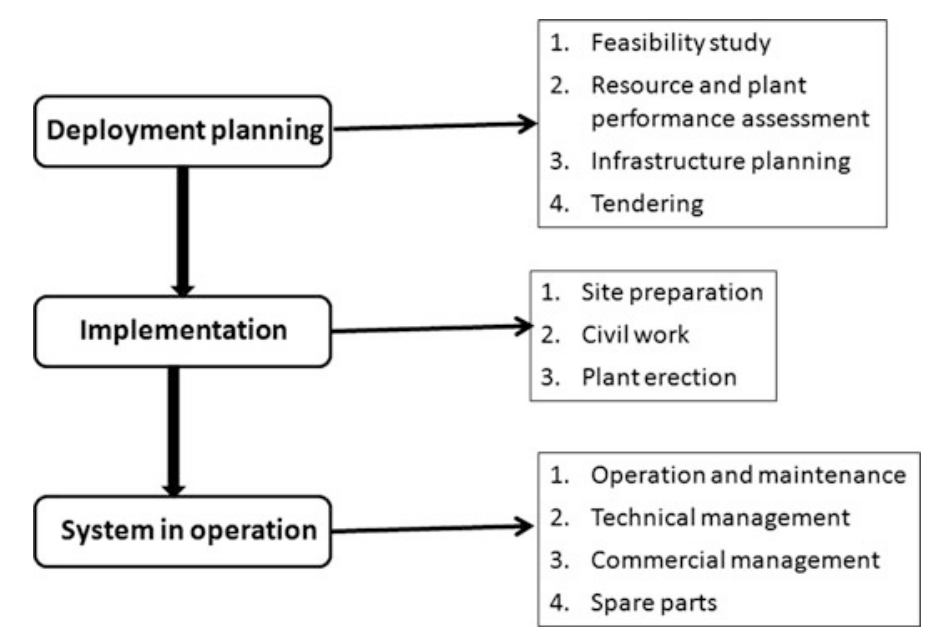

Fig. 5.1 Chain of energy project deployment

Fig. 5.1, the impacts occur at different phases of the deployment: from the deployment-planning phase to the system operation phase [11].

During these phases, the involvements of the local experts, consultants and specialized firms are necessary. In the deployment-planning phase, the involvements are in the feasibility studies, the resource and plant performance assessment, the infrastructure planning and the tendering. In the implementation phase, the involvements are in the site preparation, the civil work and eventually in the plant erection. Finally, for the system operation, the involvements are in the actions of operation and maintenance, the technical management, the commercial activities and the renewable energy parts manufacturing.

For the local involvements to be successful, there should be sound supporting processes. These processes include [11]:

- Policymaking: local policy makers and administrations play, through deployment strategies and policies, a central role in ensuring an effective deployment of the renewable energy.

- Finance: finance services are important as they play a major role not only in renewable energy investment promotion but also in attracting international investors and finance management.

- Education and capacity building: these two actions are necessary for the supply of the local qualified labor and for the creation of innovative businesses and firms. It is also the best way of ensuring a sound technology transfer.

- Research and development: It is by all means the way to ensure growth and innovation. Indeed, it is through research and development that innovative technologies could be implemented. In the long term, it ensures efficient, sound and economically viable energy systems. 
- Creation of small and medium enterprises (SME) and small and medium industries (SMI): the establishment of these SME/SMI ensures not only creation of jobs but also economic growth. It ensures also the availability of service entities that insure, among others, maintenance and spare parts.

- Renewable energy and related industry: the development of a local industrial tissue is essential for an efficient and economically viable renewable energy deployment. This industry could include raw materials as well as component production and assembly.

\subsubsection{Health Impacts}

An analysis of the African primary energy use shows that the use of traditional biomass fuel, constituted mainly of firewood and charcoal, outweighs the demand for all other forms of energy combined. The share of biomass fuel in the primary energy mix is more than $84 \%$ in the residential sector and about $7 \%$ in the industrial sector [12].

Figure 5.2 shows the percentage of the population that rely on biomass bio-fuel. It can be noted from this Figure that $60 \%$ of the African population, i.e. about 730 million, rely on polluting fuel. In the case of Benin, Burkina Fasso and more particularly Uganda, this percentage is very high; it is more than $94 \%$ [12]. It should also noted that almost 850 million have no access to clean cooking.

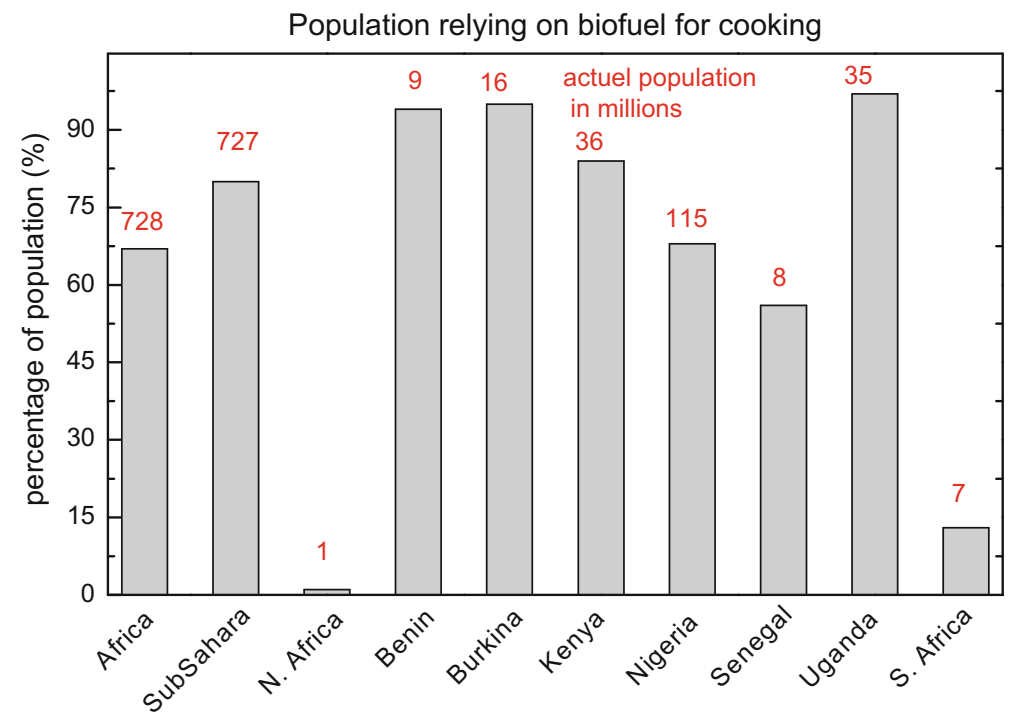

Fig. 5.2 Portion of the African population relying on biofuel [12] 
The traditional use of biofuel not only causes pollution and leads to deforestation but is also a major source of health problems. It has been reported that the use of firewood or charcoal stoves are the reason for the spread of very serious illnesses such as respiratory infections, strokes, lung cancer and pulmonary diseases. These low efficiency stoves expose people living in particularly poorly ventilated houses to carbon monoxide and other toxic matters. Women and infants, who spend most of the time indoor, suffer the most.

The deployment of renewable energy introduces affordable, clean and modern energy technologies. This reduces and eventually phases out the need for traditional biomass fuel. This undoubtedly facilitates the introduction of clean energy and modern technology stoves. This leads to a drastic reduction of indoor pollution, reducing and eventually eliminating the health threat associated with this phenomenon. Infants and women wellbeing would then increase.

Moreover, the deployment of renewable energy can improve people's health by enhancing health services. Survey by the World Health Organization has found that actually $58 \%$ of health institutions in a large number of African countries have no access to electricity [12]. Indeed, by assuring the electrification of the health institution infrastructures, it is possible to offer modern health services such as the use of modern health equipment for diagnostic and treatment [13]. Electricity is needed for refrigeration of pharmaceutical products, medical tools sterilization and for emergency procedures.

\subsubsection{Impacts on Education}

Actually, a large number of African primary schools are without electricity. It has been falsely argued that schooling takes place during the day. This argument has led to many African countries, as shown in Fig. 5.3, neglecting school electrification. As shown from this Figure, only five countries, namely, Djibouti, Guinea-Bissau, Namibia, Rwanda and Swaziland reported primary school electrification rate higher than the national electrification rate. For at least $12.5 \%$ of the African countries, the primary school electrification rate is less than 5\%. Central African Republic holds the grim record of no primary school electrification. It should be noted that Seychelles and Mauritius have full primary school electrification, while Algeria has a $97 \%$ public school electrification [14].

Arguing that schooling takes place during daytime in order to delay school electrification is false and harmful. It is false as schooling could be extended to after daytime and that homework and class preparation usually take place at night. It is also false in the sense that electricity is needed not only for lighting but also for the energy that powers equipments, such as computers and laboratory instrumentations that are necessary for the education. It is harmful in the sense that the process that ensure the provision of a quality education is overlooked. Indeed, a lack of electrification usually leads not only to pupils' failure with a large drop out but this could hinder the attraction of the most competent teachers and their retention. 


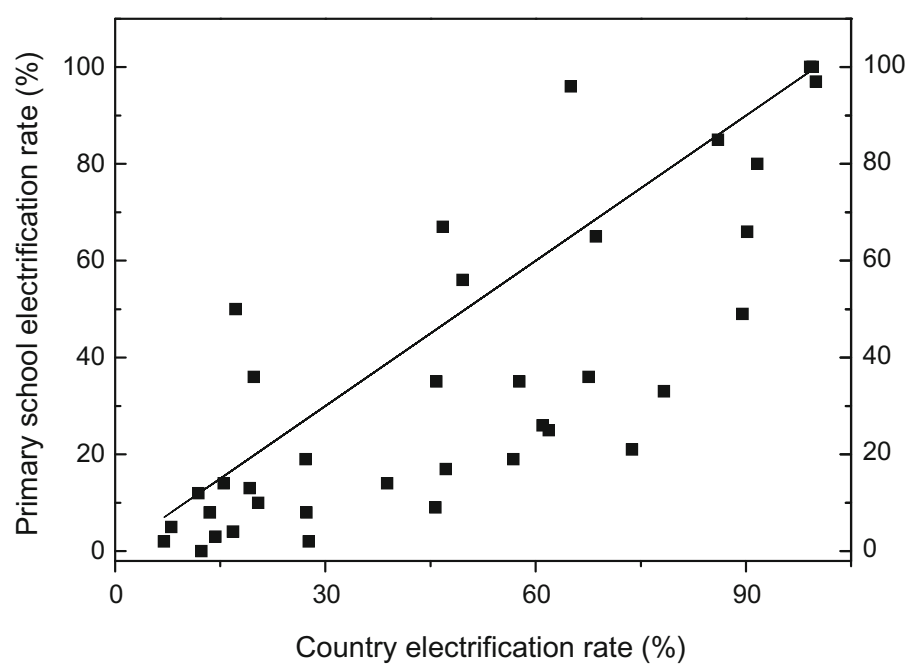

Fig. 5.3 Primary school electrification rate as function of the country electrification rate for African countries (source data $[1,14]$ )

Renewable energy deployment, by its flexibility and adaptability to different regions, is capable of ensuring a viable schools electrification. Among the positive impacts of the renewable, there is [15].

(a) Light and study time: In most non-electrified African schools, school attendance is limited to daytime. Moreover, in this case, homework and course preparation are usually carried out using inefficient, polluting and health threatening kerosene lamps. Electrification enables the provision of clean lightening. Studies have shown that the electricity light is cleaner and economically more viable [16]. Moreover, the electricity light allows an increase in the use of the school infrastructure. This allows the extension of teaching time to early morning and to late afternoon [17]. School infrastructures could also be used by pupils to do homework and by teachers to prepare courses. Studies have shown that school electrification increases youth literacy rate [18].

(b) School performance: Undoubtedly, school electrification has positive impact on school performance, leading to less absenteeism, more enrolments and larger numbers of graduation. Studies carried out in Sudan, Tanzania and Kenya [19] have shown that school electrification result in doubling the number of pupils completing their academic curriculum. It has been argued that providing electricity leads to a much better academic performance [20].

(c) ICT as education tools: Information and communications technologies (ICT) offer many opportunities for high quality education experiences, both in-class as well as through e-learning. Experiences in using renewable energy for ICT introduction in schools have been successfully carried out [21]. Renewable energy deployment holds promises for a strong ICT involvement in education. 
The ICT technologies include telephone, radio, television, audio and video tapes. These technologies have enhanced the pupils' ability to learn and improve their academic achievements [22]. But it is with the advent of computer and internet that ICT became potent central tools for education and information gathering [23]. In Africa, Rwanda and Namibia have taken steps for ICT introduction in Education [22].

(d) Teacher attraction and retention: Best teachers usually choose schools that offer them the best chance to develop their skills and to evolve by acquiring new ones. It is no surprise that school electrification is at the top of their choice [24]. Indeed, electrification enables them to acquire the tools, such as ICT, which facilitate their teaching and allow them to progress in their career.

(e) Gender enrolment: School electrification has increased girls' enrolment in education. Studies have shown that there is a direct correlation between school electrification and the ratio of girl-to-boy enrolment in school [25]. School electrification in the mostly nomad populated area of southern Algeria has been the best way of convincing the nomad population to enrol their children in boarding schools [26].

\subsubsection{Impacts on Rural Development}

Rural area dwellers lag urban dwellers in access to electricity and to clean fuels and technologies for cooking. Figure 5.4 reports the electrification rates for Africa as a

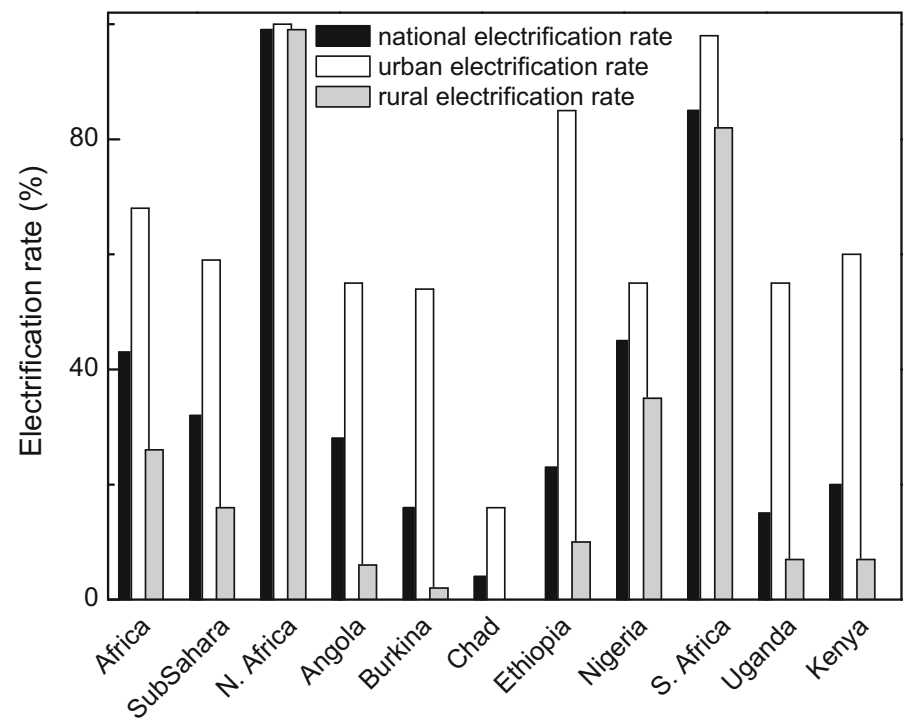


whole and for different African countries. From this Figure, it can be noted that at the African level, the urban electrification rate is $161 \%$ more important than the rural one. For some countries, such as Angola, Burkina Faso and Kenya, the rural electrification rate is extremely low. For these countries, the urban electrification rates are respectively 817,2600 and $757 \%$ more important than the rural electrification rates. It has been reported that about 480 million rural Africans have no access to electricity [27].

This could be explained in part by the power grid system adopted by the African countries. This system is centralized and as such is not well adapted to scarcely populated areas such as the Sahara and the Kalahari deserts or to scattered dwellings such as the case of the African rural areas. It should be noted that $60 \%$ of the African population live in such areas. The extension of the centralized grid to these scarcely populated or scattered dwellings areas is financially prohibitive and technically challenging.

Nonetheless, the off-grid technologies, using renewable energy sources, have proven to be appropriate for the electrification of the rural areas. These technologies, either on stand-alone, micro-grid or mini-grid, have become the options for localities where central grid connections are neither available nor affordable.

The first impact is an improvement in human health and a reduction of indoor pollution, as a result of replacing kerosene lamps by electricity for lighting and firewood stoves by modern stoves for cooking.

With electrification, there are possibilities of using household appliances, such as refrigerators and blenders. This has the effect of not only improving people's diet but also saving time that could be used in more productive activities.

Electrification offers also the opportunities for local education. Studies have shown that rural electrification has led to an increase in rural school enrolment [28] and to a reduction in rural exodus [29].

Electrification can also boost agriculture productivity. By allowing irrigation through water pumping and by permitting crops storages and processing, electrification offer the opportunity to the farmers to contribute to the agro-industry sector and by that increase their incomes.

\subsection{Conclusion}

Africa's energy deficits and technical power problems have been hampering its sustainable economic growth. To solve these problems, the African countries are resorting to the development of their important renewable energy potential. National energy programs have been devised and policy instruments for their implementations identified.

An analysis of the renewable energy deployment economy shows that wind energy and solar PV are viable and competitive with conventional energy. Moreover, renewable energy deployment impacts positively on socio-economic progress, health, education, gender equity and rural development. 


\section{References}

1. Worldbank datadbank. http://databank.worldbank.org/data/databases.aspx

2. A. Eberhard, O. Rosnes, M. Shkaratan, H. Vennemo, in Africa's Power Infrastructure: Investment, Integration, Efficiency (The World Bank, Washington DC, 2011)

3. IEA, Energy Access Outlook 2017, World Energy Outlook Special Report (2017)

4. Black \& Veatch, in Cost and Performance Data for Power Generation Technologies. Report prepared for the National Renewable Energy Laboratory (2012). http://bv.com/docs/reportsstudies/nrel-cost-report.pdf

5. Energy and Environmental Economics. Capital Cost Review of Power Generation Technologies: Recommendations for WECC's 10- and 20-Year Studies (San Francisco, CA, 2014)

6. G. Schwerhoff, M. Sy, Financing renewable energy in Africa-key challenge of the sustainable development goals. Renew. Sustain. Energy Rev. 75, 393-401 (2017)

7. A. Brown, P. Beiter, D. Heimiller, C. Davidson, P. Denholm, J. Melius, A. Lopez, D. Hettinger, D. Mulcahy, G. Porro, Estimating Renewable Energy Economic Potential in the United States: Methodology and Initial Results, Technical Report NREL/TP-6A20-64503 National Renewable Energy Laboratory Revised August 2016

8. US-IEA, Levelized Cost and Levelized Avoided Cost of New Generation Resources, Annual Energy Outlook 2017

9. REN21, Renewables 2016, Global Status report. www.ren21.net

10. Irena, Renewable Energy Technologies Cost Analysis Series, Volume 1: Power Sector, Concentrating Solar Power, June 2012

11. IRENA, The socio-economic benefits of solar and wind energy (2014). www.irena.org/ Publications

12. J. Lee, 5 Reasons to care about access to electricity, United Nations Foundation (August 2013). http://www.unfoundation.org/blog/5-reasons-electricity.html

13. UNESCO Institute for Statistics, A view inside schools in Africa: regional education survey (2014)

14. UNDESA, Energy and Education 1: electricity and education: the benefits, barriers, and recommendations for achieving the electrification of primary and secondary schools (December 2014)

15. E. Adkins, S. Eapen, F. Kaluwile, G. Nair, V. Modi, Off-grid energy services for the poor: introducing LED lighting in the Millennium Villages Project in Malawi. Energy Policy 38, 1087-1097 (2010)

16. C. Kirubi, A. Jacobson, D. Kammen, A. Mills, Community-based electric micro-grids can contribute to rural development: evidence from Kenya. World Dev. 37(7), 1208-1221 (2009)

17. A.S.A.C. Diniz, E.D. França, C.F. Câmara, P.M.R. Morais, L. Vilhena, The important contribution of photovoltaics in a rural school electrification program, in Transactions of the IEEE (2006), pp. 2528-2531

18. Phil Goodwin, The dark side of education (October 8, 2013)

19. M.P. Bacolod, J.L. Tobias, Schools, school quality and achievement growth: Evidence from the Philippines. Econ. Edu. Rev. 25, 619-632 (2006)

20. B.K. Sovacool, S.E. Ryan, The geography of energy and education: leaders, laggards, and lessons for achieving primary and secondary school electrification. Renew. Sustain. Energy Rev. 58, 107-123 (2016)

21. UNESCO, Transforming Education: The Power of ICT Policies (UNESCO, Paris, 2011)

22. M.D. Chinn, R.W. Fairlie, The determinants of the global digital divide: a crosscountry analysis of computer and internet penetration, Oxf. Econ. Pap. December 3 (2006)

23. UNESCO Teaching and Learning, Achieving Quality for All (UNESCO, Paris, 2014)

24. B.K. Sovacool, S. Clarke, K. Johnson, M. Crafton, J. Eidsness, D. Zoppo, The energy-enterprise-gender nexus: lessons from the multifunctional platform (MFP) in Mali. Renew. Energy 50, 115-125 (2013) 
25. A. Khellaf, F Khadri, S. Guezzane, Photovoltaic option in Algeria: current action, in Euro-Mediterranean Workshop on Euro-Mediterranean Renewable Energies (European Commission's INCO Program, Nicosia, Cyprus, May 18-21, 2002)

26. T. Bernard, Impact Analysis of rural electrification projects in Sub-Saharan Africa. World Bank Res. Observer 27(1), 33-51 (2012)

27. IEA, World Energy outlook 2014, Traditional use of Biomass for cooking (2014)

28. J. Ter-Wengel, The effects of electrification and the extension of education on the retention of population in rural areas of Colombia, in Impact of Rural Development Projects on Demographic Behaviour, ed. by R.E. Bilsborrow, P.F. DeLargy (New York, United Nations Fund for Population Activities, New York, 1985), pp. 47-64

29. A. Gurung, Om Prakash Gurung, Sang Eun Oh, the potential of a renewable energy technology for rural electrification in Nepal: a case study from Tangting. Renew. Energy 36, 3203-3210 (2011)

Open Access This chapter is licensed under the terms of the Creative Commons Attribution 4.0 International License (http://creativecommons.org/licenses/by/4.0/), which permits use, sharing, adaptation, distribution and reproduction in any medium or format, as long as you give appropriate credit to the original author(s) and the source, provide a link to the Creative Commons license and indicate if changes were made.

The images or other third party material in this chapter are included in the chapter's Creative Commons license, unless indicated otherwise in a credit line to the material. If material is not included in the chapter's Creative Commons license and your intended use is not permitted by statutory regulation or exceeds the permitted use, you will need to obtain permission directly from the copyright holder.

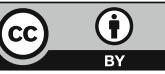

